\title{
Heavy Metals in Air Nanoparticles in Affected Industry Area
}

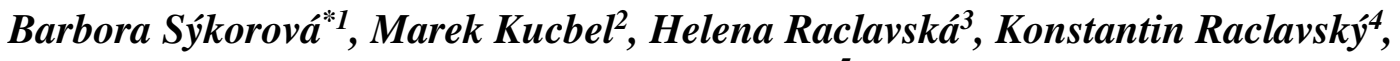 \\ Dalibor Matýsek \\ ${ }^{1}$ ENET Centre - Energy Units for Utilization of non Traditional Energy Sources, \\ VŠB - Technical University of Ostrava, 70833 Ostrava - Poruba, Czech Republic \\ e-mail: barbora.sykorova@vsb.cz \\ ${ }^{2}$ ENET Centre - Energy Units for Utilization of non Traditional Energy Sources, \\ VŠB - Technical University of Ostrava, 70833 Ostrava - Poruba, Czech Republic \\ e-mail: marek.kucbel@vsb.cz \\ ${ }^{3}$ ENET Centre - Energy Units for Utilization of non Traditional Energy Sources, \\ VŠB - Technical University of Ostrava, 70833 Ostrava - Poruba, Czech Republic \\ e-mail: helena.raclavska@vsb.cz \\ ${ }^{4}$ ENET Centre - Energy Units for Utilization of non Traditional Energy Sources, \\ VŠB - Technical University of Ostrava, 70833 Ostrava - Poruba, Czech Republic \\ e-mail: konstantin.raclavsky@vsb.cz \\ ${ }^{5}$ Institute of Geological Engineering, VŠB - Technical University of Ostrava, \\ 70833 Ostrava - Poruba, Czech Republic \\ e-mail: dalibor.matysek@vsb.cz
}

\begin{abstract}
The Moravian-Silesian Region is one of the most polluted sites by dust particles in the Czech Republic. Therefore, atmospheric concentrations of heavy metals as cadmium, cobalt, chromium, copper, nickel, lead, antimony, thallium, manganese, iron and zinc, were monitored at 10 localities in the region during summer of 2014. Heavy metals were monitored in 10 particle size classes from $18.3 \mathrm{~nm}$ to $9.93 \mu \mathrm{m}$. The percentage of the amount of heavy metals in the sum PM at all localities ranged from 0.2-2.5\%. It was found that chromium, manganese, iron and zinc were mostly accumulated in dust particles with diameter greater than $1.6 \mu \mathrm{m}$. Lead, cadmium and antimony occur mainly in the class below $0.949 \mu \mathrm{m}$. These metals are more dangerous for human health, and can have potential carcinogenic effect. The influence of metallurgical industry evaluated on the basis of heavy metals in the individual particle size classes in the air within the Moravian-Silesian Region has not been unequivocally demonstrated.
\end{abstract}

\section{KEYWORDS}

Metallurgical industry, Heavy metals, Dust particles, Nanoparticles, Size distribution of heavy metal.

\section{INTRODUCTION}

The highest concentration of emissions of Particulate Matter (PM) in the atmosphere occurs in the Moravian-Silesian Region. The Ostrava-Karvina area is among the most polluted areas not only within the country but also in Europe. Inclusion among the areas

\footnotetext{
* Corresponding author
} 
with poor air quality is mainly due to excess concentrations of suspended particulate matter $\mathrm{PM}_{10}$. This is due to the high concentration of industries in this area. Metallurgical industry such as Třinecké železárny - Moravia Steel and ArcelorMittal Ostrava produces up to $590 \mathrm{t}$ of PM/year in each company.

Metals in air are most often bound to dust particles that have a different aerodynamic diameter. In suspended particles, the ability to bind heavy metals increases with their decreasing size [1]. Heavy metals bound on dust particles in the air are affected by the processes occurring in the atmosphere only to a very low extent. Therefore, they can be used as useful indicators of pollution sources. The main anthropogenic sources of heavy metals as Vanadium (V), Cobalt (Co), Molybdenum (Mo), Nickel (Ni), Antimony $(\mathrm{Sb})$, Chromium $(\mathrm{Cr})$, Iron ( $\mathrm{Fe})$, Manganese $(\mathrm{Mn})$ and Tin $(\mathrm{Sn})$ include the combustion of fossil fuels; metals from industrial metallurgical processes are Arsenic (As), Cr, Copper $(\mathrm{Cu}), \mathrm{Mn}$ and Zinc $(\mathrm{Zn})$; road transport produces Fe, Barium $(\mathrm{Ba})$, Lead $(\mathrm{Pb}), \mathrm{Cu}$, $\mathrm{Zn}$ and Cadmium (Cd) [2]. Metals from waste incineration are $\mathrm{Zn}, \mathrm{Pb}, \mathrm{Cu}, \mathrm{Cd}$ and Mercury $(\mathrm{Hg}) . \mathrm{Zn}$ and $\mathrm{Pb}$ are mainly produced during the manufacture of iron and steel. During the processing of non-ferrous metals $\mathrm{As}, \mathrm{Sb}, \mathrm{Cu}, \mathrm{Zn}, \mathrm{Pb}, \mathrm{Cd}$ and $\mathrm{Hg}$ are released into the atmosphere; during the production of copper it is $\mathrm{Cu}$ and $\mathrm{Zn}$ [3].

Trace elements originating from anthropogenic activities accumulate in fine-particulate matter with aerodynamic diameter $<2.5 \mu \mathrm{m}$, elements derived from natural sources are mainly present in particles larger than $2.5 \mu \mathrm{m}$ [4]. These particles also contain metals released mainly from mechanical processes, e.g. resuspension of road dust, abrasion of tires and brake linings [5].

The solid particles contain particularly: $\mathrm{V}, \mathrm{Ni}, \mathrm{Cd}, \mathrm{Pb}$, which come from the high temperature processes such as the combustion of coal and waste [6]. Other metals such as $\mathrm{Zn}$, Co, Mo, $\mathrm{Cr}$ come from both the mechanical and high temperature processes and occur in particles below and above $2.5 \mu \mathrm{m}$ [7]. Iron, strontium (Sr) and barium accumulate mainly in larger particles with grain size 3-4 $\mu \mathrm{m}$. This distribution of metals in PM is the result of a combination of processes in the atmosphere, local anthropogenic and natural resources, and remote transfer.

The impact of heavy metals on environment and human health is dependent on mobility of each metal and its occurrence in various components of the environment [8]. The long exposure of human organism to heavy metals is associated with many health risks e.g. development retardation, various forms of cancer and renal deficiency [9]. In addition, a long exposure can cause damage of plants, decrease of yield in agriculture, deterioration of soil structure and contamination of ground or surface water [10]. Many things manufactured from metal are endangered and damaged by accelerated corrosion [11]. Atmospheric deposition of heavy metals in the vicinity of metallurgical plants can influence the vegetation growing and can be responsible for damage of physiological functions of living organisms through food chains [12]. Approximately $70-90 \%$ of heavy metals are distributed in the particles of size smaller than $\mathrm{PM}_{10}$. The concentration of metals increases with decreasing particle size [13]. Potentially toxic metals, e.g. nickel, lead and cadmium are accumulated in the urban environment mainly in the particles of aerodynamic diameter $<1 \mu \mathrm{m}[14]$.

The aim of this work is to identify priority occurrence of metal nanoparticles with possible identification of sources of influence on this distribution. Information on the distribution of metals in nanoparticles is new in the literature.

\section{SAMPLING AND METHODS}

Various metals as $\mathrm{Cd}, \mathrm{Co}, \mathrm{Cr}, \mathrm{Cu}, \mathrm{Ni}, \mathrm{Pb}, \mathrm{Sb}$, thallium (Tl), $\mathrm{Mn}, \mathrm{Fe}$ and $\mathrm{Zn}$ were observed in nanoparticles in the air within the Moravian-Silesian Region, the Czech Republic. Sampling was performed in the summer season (from June to August) due to 
the assessment of the impact of large industrial sources as metallurgy and minimizing the impact of local heating on air quality.

Sampling of dust particles was performed at ten selected locations (Figure 1), using an electric low-pressure cascade impactor- ELPI ${ }^{+}$, Dekati Company. These 10 locations were chosen from the 40 sampling sites selected for monitoring the composition of PM. $\mathrm{ELPI}^{+}$spectrometer was used for measuring the particle size distribution. The device can be used as on-line, using information about the number of particles, particle volume, weight of the particles, etc. from the software of the device, or also as an off-line device, capture of dust particles which can be subsequently subjected to chemical analysis. The cascade impactor system can separate the particle matter following aerodynamic equivalent cut-off diameter at 50\% efficiency in 14 particle size fractions ranging from $18.3 \mathrm{~nm}$ to $9,930 \mathrm{~nm}$. The particles are charged in a positive unipolar particle charger corona charger according to their Stokes diameter before entering the impactor stages. After being charged by the corona charger, the atmospheric particles are introduced in the impactor in order to be classified owing to their aerodynamic diameter and inertia. A multistage electrometer enables counting the charged aerosol particles. The current is simultaneously measured for the 14 impactor stages and directly converted by the electrometer in particles number and concentrations using mathematical algorithms [15].

To determine the distribution of iron in emissions, particulate sampling was performed using gravimetric isokinetic kit TESO GTE equipped with the control and evaluation system IZOMAT. Particulate sampling was carried out applying the method ISO 9096/EPA/ČSN EN 14385 by the company Technical Services for Air Protection Ostrava - TESO Ostrava. Emissions were categorized into three particle size classes: below $2.5 \mu \mathrm{m}, 2.5-10 \mu \mathrm{m}$, and over $10 \mu \mathrm{m}$. Emissions were sampled from ten large energy sources at 16 boilers, six technological processes in the two ironworks: ArcellorMittal and Třinecké železárny - Moravia Steeland for four technological processes in the coking plants.

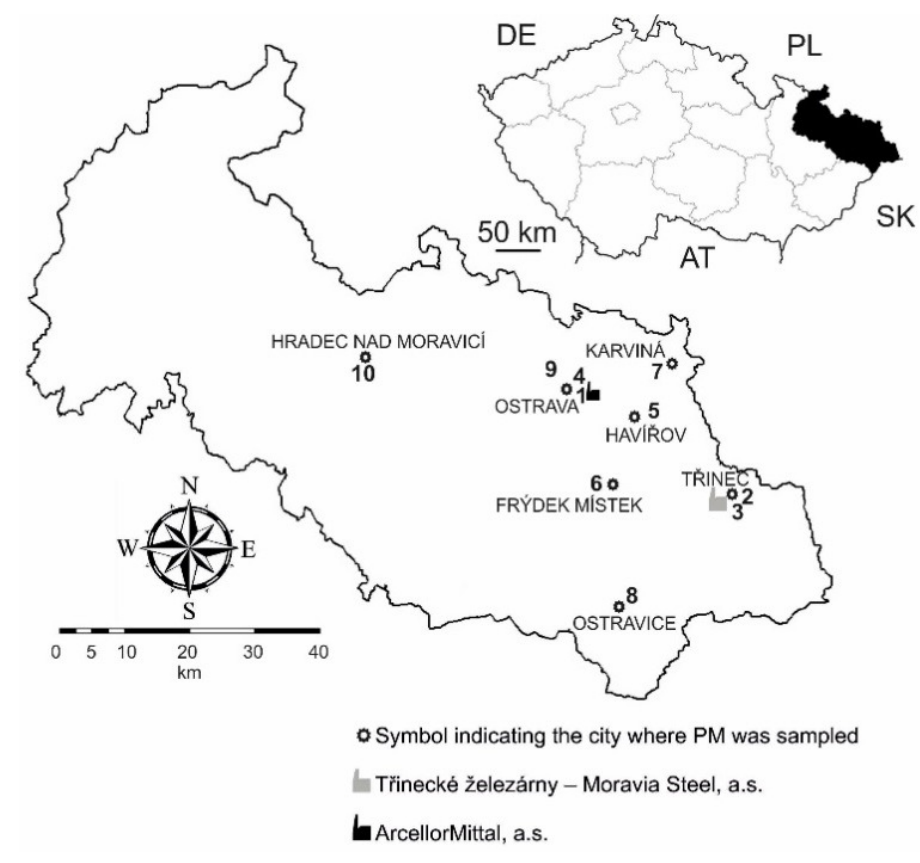

Figure 1. Sampling sites: Ostrava Radvanice (1); Třinec (2); Třinec Oldřichovice (3); Ostrava Mariánské Hory (4); Havírov (5); Frýdek Místek (6); Karviná (7); Ostravice (8); Ostrava Poruba (9); Hradec nad Moravicí (10)

Samples of emissions and air pollution were decomposed in the microwave equipment in a mixture of acids $\mathrm{HF}, \mathrm{HCl}, \mathrm{HNO}_{3}$ and $\mathrm{H}_{2} \mathrm{O}_{2}$, followed by ICP analysis 
carried out in the laboratories of the Czech Geological Survey (CGS), Prague. For samples from two localities, namely Ostrava Marianské Hory and Ostrava Radvanice, the chemical nature of the particles in the class below $1 \mu \mathrm{m}$ was monitored using microanalysis. Analysis of $\mathrm{PM}_{10}$ particles retained on the filters was performed by Scanning Electron Microscope (SEM) (FEI Quanta 650 FEG), using the energy dispersive analyser EDAX.

Based on the mineralogical analysis of Total Suspended Particles (TSP), specifically content of hematite [16] and magnetite [17], the localities were divided into 4 groups. Hematite and magnetite are among the typical minerals forming PM that are associated with metallurgical processes, or they are used as raw materials in these processes. Matysek et al., reported that PM consisting of hematite and magnetite are able to bind heavy metals [18].

- Localities significantly affected by the metallurgical industry - 1,2 and 3;

- Localities affected by the metallurgical industry - 4, 5 and 6;

- Localities less significantly affected by the metallurgical industry -7 and 8 ;

- Localities not affected by the metallurgical industry - 9 and 10.

\section{RESULTS}

\section{The occurrence of heavy metals in dust particles}

The presence and distribution of heavy metals was studied in 10 particle size classes from 18.3-93.7 nm, 93.7-156 nm, 156-263 nm, 263-383 nm, 383-614 nm, 614-949 nm, $949 \mathrm{~nm}-1.6 \mu \mathrm{m}, 1.6-2.39 \mu \mathrm{m}, 2.39-6.69 \mu \mathrm{m}$ and 6.69-9.93 $\mu \mathrm{m}$ (Figure 2).

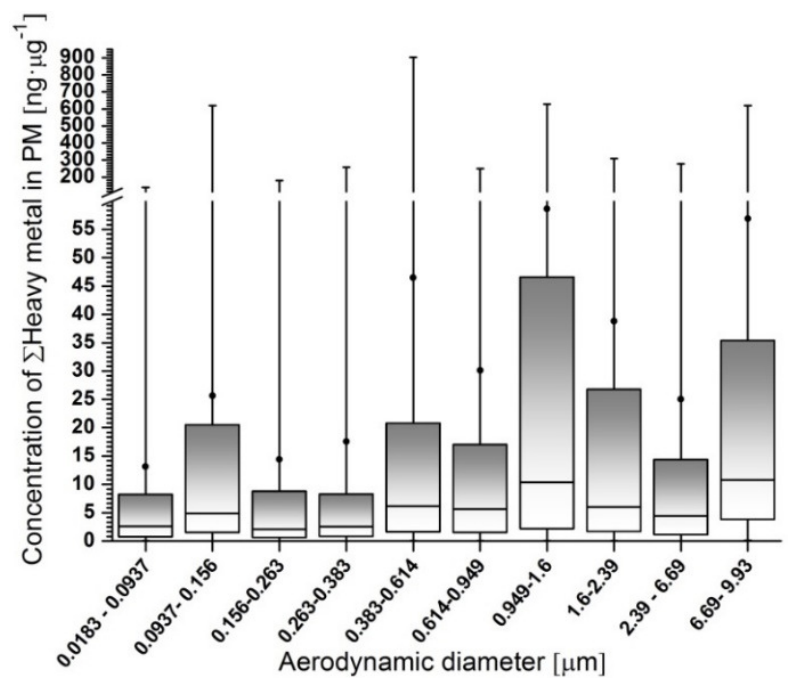

Figure 2. Concentration of sum of heavy metals in $\mathrm{PM}_{10}$ particle size class

From the sum of metals in PM (Figure 3), it is evident that they occurred mainly in the grain size classes: 0.093-0.156 $\mu \mathrm{m}, 0.383-0.949 \mu \mathrm{m}, 0.949-1.6 \mu \mathrm{m}$, and $6.69-9.93 \mu \mathrm{m}$. The results stated in Table 1 show that based on the arithmetic average for the 10 localities, most metals occur mainly in the class from 1 to $2.5 \mu \mathrm{m}$, namely $\mathrm{Cd}$, Co, $\mathrm{Pb}, \mathrm{Sb}$, and $\mathrm{Zn}$, only the concentration of $\mathrm{Cu}$ and $\mathrm{Ni}$ is higher in the class from 2.5-9.93 $\mu \mathrm{m}$. For metals $\mathrm{Cd}, \mathrm{Tl}, \mathrm{Pb}$, it has been found that a substantial amount is present in the particle size class PM $1-2.5 \mu \mathrm{m}$. The concentration of manganese, iron and chromium are almost comparable in both particle size classes 1-2.5 $\mu \mathrm{m}, 2.5-9.93 \mu \mathrm{m}$. In the class below one $\mu \mathrm{m}$, mostly secondary aerosols composed of sulphates, nitrates, ammonium ions, and $\mathrm{Ca}^{2+}, \mathrm{Mg}^{2+}, \mathrm{Na}^{+}, \mathrm{K}^{+}$ions occur [18], therefore the metal content is minimal. 


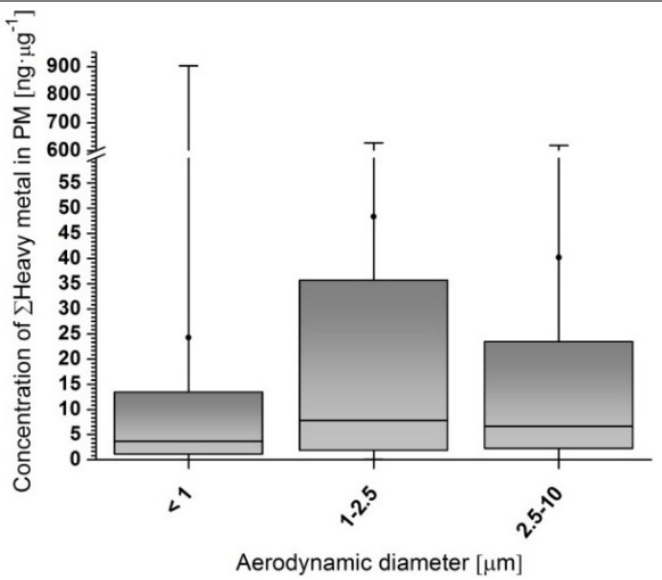

Figure 3. Concentrations of sum of heavy metals in $<\mathrm{PM}_{1}, \mathrm{PM}_{1-2.5}, \mathrm{PM}_{2.5-10}$ classes

Table 1. Metal contents in individual particle size classes in $\mathrm{ng} / \mu \mathrm{g}$

\begin{tabular}{|c|c|c|c|c|c|c|c|}
\hline & {$[\mu \mathrm{m}]$} & $N$ total & Mean & St. deviation & Minimum & Median & Maximum \\
\hline \multirow{3}{*}{$\mathrm{Cd}$} & $<1$ & 31 & 0.12 & 0.14 & 0.03 & 0.07 & 0.76 \\
\hline & $1-2.5$ & 5 & $0.46^{*}$ & 0.79 & 0.06 & $0.13^{*}$ & 1.87 \\
\hline & $2.5-10$ & 3 & 0.12 & 0.11 & 0.02 & 0.11 & 0.23 \\
\hline \multirow{3}{*}{$\mathrm{Co}$} & $<1$ & 6 & 0.13 & 0.09 & 0.06 & 0.07 & 0.25 \\
\hline & $1-2.5$ & 3 & $0.28^{*}$ & 0.38 & 0.06 & 0.06 & 0.71 \\
\hline & $2.5-10$ & 3 & 0.13 & 0.12 & 0.03 & $0.09^{*}$ & 0.26 \\
\hline \multirow{3}{*}{$\mathrm{Cr}$} & $<1$ & 59 & 6.50 & 4.80 & 1.32 & 5.07 & 23.00 \\
\hline & $1-2.5$ & 20 & $13.62^{*}$ & 10.87 & 3.86 & 9.95 & 46.59 \\
\hline & $2.5-10$ & 20 & 13.57 & 10.52 & 2.36 & $10.24^{*}$ & 35.37 \\
\hline \multirow{3}{*}{$\mathrm{Cu}$} & $<1$ & 13 & 2.84 & 2.91 & 0.06 & 2.26 & 8.86 \\
\hline & $1-2.5$ & 5 & 1.07 & 0.58 & 0.32 & 1.13 & 1.87 \\
\hline & $2.5-10$ & 5 & $5.10^{*}$ & 5.13 & 1.86 & $2.81^{*}$ & 13.99 \\
\hline \multirow{3}{*}{$\mathrm{Fe}$} & $<1$ & 54 & 126.27 & 159.93 & 19.04 & 71.50 & 902.81 \\
\hline & $1-2.5$ & 19 & $279.09^{*}$ & 250.38 & 58.93 & $248.22^{*}$ & $1,189.14$ \\
\hline & $2.5-10$ & 19 & 242.77 & 173.76 & 53.37 & 231.18 & 619.00 \\
\hline \multirow{3}{*}{$\mathrm{Mn}$} & $<1$ & 60 & 3.92 & 5.19 & 0.07 & 2.00 & 30.06 \\
\hline & $1-2.5$ & 20 & $6.57^{*}$ & 5.52 & 1.26 & 5.39 & 22.17 \\
\hline & $2.5-10$ & 20 & 5.76 & 4.55 & 1.08 & $5.76^{*}$ & 15.73 \\
\hline \multirow{3}{*}{$\mathrm{Ni}$} & $<1$ & 36 & 1.65 & 1.51 & 0.13 & 1.02 & 5.77 \\
\hline & $1-2.5$ & 12 & 3.75 & 4.34 & 0.53 & 1.82 & 13.20 \\
\hline & $2.5-10$ & 13 & $4.34^{*}$ & 3.77 & 0.65 & $3.62^{*}$ & 10.81 \\
\hline \multirow{3}{*}{$\mathrm{Pb}$} & $<1$ & 59 & 2.49 & 2.80 & 0.21 & 1.33 & 13.57 \\
\hline & $1-2.5$ & 20 & $5.21^{*}$ & 8.79 & 0.27 & $1.89^{*}$ & 31.27 \\
\hline & $2.5-10$ & 20 & 2.19 & 2.25 & 0.19 & 1.10 & 7.20 \\
\hline \multirow{3}{*}{$\mathrm{Sb}$} & $<1$ & 33 & 1.81 & 2.52 & 0.07 & $1.00^{*}$ & 12.71 \\
\hline & $1-2.5$ & 8 & $5.88^{*}$ & 12.70 & 0.26 & 0.64 & 36.87 \\
\hline & $2.5-10$ & 8 & 1.91 & 2.64 & 0.09 & 0.39 & 7.27 \\
\hline \multirow{3}{*}{$\mathrm{Tl}$} & $<1$ & 19 & 2.41 & 1.79 & 0.62 & 1.57 & 5.81 \\
\hline & $1-2.5$ & 4 & $10.06^{*}$ & 11.56 & 1.66 & $6.21^{*}$ & 26.16 \\
\hline & $2.5-10$ & 4 & 6.35 & 7.82 & 0.72 & 3.42 & 17.84 \\
\hline \multirow{3}{*}{$\mathrm{Zn}$} & $<1$ & 59 & 17.88 & 20.94 & 2.18 & 10.59 & 99.97 \\
\hline & $1-2.5$ & 20 & $27.39^{*}$ & 27.61 & 6.65 & $18.04^{*}$ & 116.07 \\
\hline & $2.5-10$ & 20 & 21.16 & 15.46 & 3.81 & 15.87 & 56.07 \\
\hline
\end{tabular}

${ }^{*}$ Number denote maximum value 
$\mathrm{Fe}$ accounts for up to $87 \%$ of the total amount of monitored trace elements [19]. Trace elements usually represent only 5\% of the total amount in $\mathrm{PM}_{10}$. At all 10 localities, iron is the major element occurring in the range of $75-87 \%$ from the sum of monitored metals. The lowest content $-518 \mathrm{ng} / \mu \mathrm{g}$ was found in Ostravice, $75 \%$. Fe particles in $\mathrm{PM}_{10}$ produce four chemically different groups: Fe-rich particles (r-Fe) K-rich Fe particles, $\mathrm{Fe}$ particles containing $\mathrm{V}$, and mineral particles as soil particles, particles released by erosion and transport of materials [20].

The second most important element in terms of the concentration is $\mathrm{Zn}$ in the range between 7.1-11\%, followed by $\mathrm{Cr}$ from $2.3-6.8 \%, \mathrm{~Pb}$ in the range $0.3-5.8 \%$, and $\mathrm{Mn}$ from 1.4-2.4\%. The lowest concentrations were found for $\mathrm{Cd}, \mathrm{Co}, \mathrm{Cu}, \mathrm{Ni}, \mathrm{Tl}$, and $\mathrm{Sb}$; up to $0.5 \%$ in $\Sigma$ metals.

The results of the distribution of iron in emissions, see Figure 4, show that in the case of the large energy resources, iron concentration decreases with increasing particle size. For emissions from metallurgy, in the class 2.5-10 $\mu \mathrm{m}$ higher concentrations were observed than in the class below $2.5 \mu \mathrm{m}$ - the difference amounted to $8 \%$. For emissions from coke plants, iron is divided into classes below $2.5 \mu \mathrm{m}(44 \%)$ and the class above $10 \mu \mathrm{m}(56 \%)$.

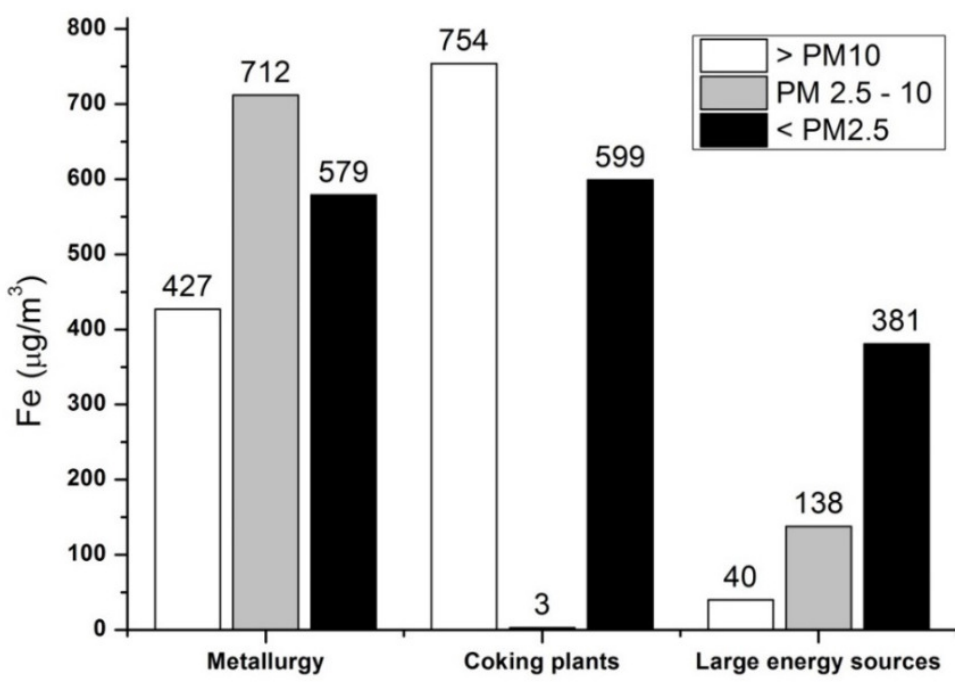

Figure 4. Distribution of Fe in emissions

The distribution of localities based on the content of hematite and magnetite in TSP does not correspond to the character of the distribution of particles in air pollution. For localities with a predominant influence of the metallurgical industry, a higher proportion of particles in the class 2.5-10 $\mu \mathrm{m}$ was expected based on the results, illustrated in Figure 5. However only the locality Třinec corresponds to this distribution. The influence of Arcelor Mittal in Ostrava Radvanice did not have any impact on the particle size distribution. Using microanalysis, Fe-oxide particles were identified in the particles below $1 \mu \mathrm{m}$ in the sample from Ostrava Radvanice; they accounted for about $20 \%$ of the particles containing $\mathrm{Fe}$ and alumosilicates with different percentage of cations: $\mathrm{Fe}, \mathrm{K}, \mathrm{Ca}$, and $\mathrm{Mg}(80 \%)$ corresponding to the high-temperature processes as fossil fuel combustion.

A high proportion of particles below $1 \mu \mathrm{m}$ in Ostrava Marianské Hory is affected by the operation of the steel plant. In particles below $1 \mu \mathrm{m}$, bianchite $(\mathrm{Zn}, \mathrm{Fe}) \mathrm{SO}_{4} .6 \mathrm{H}_{2} \mathrm{O}$, where $\mathrm{Fe}$ isomorphously replaces $\mathrm{Zn}$ in the structure, was identified using an electron microprobe. Fe-oxide particles (Fe content of 12-30\%) with higher contents of other metals: zinc (3.2-28\%), copper (1-2\%), cobalt (0.2-0.4\%), chromium (0.4-2.5\%), nickel $(0.4-1.2 \%)$, manganese (1-10\%), were identified as well. 


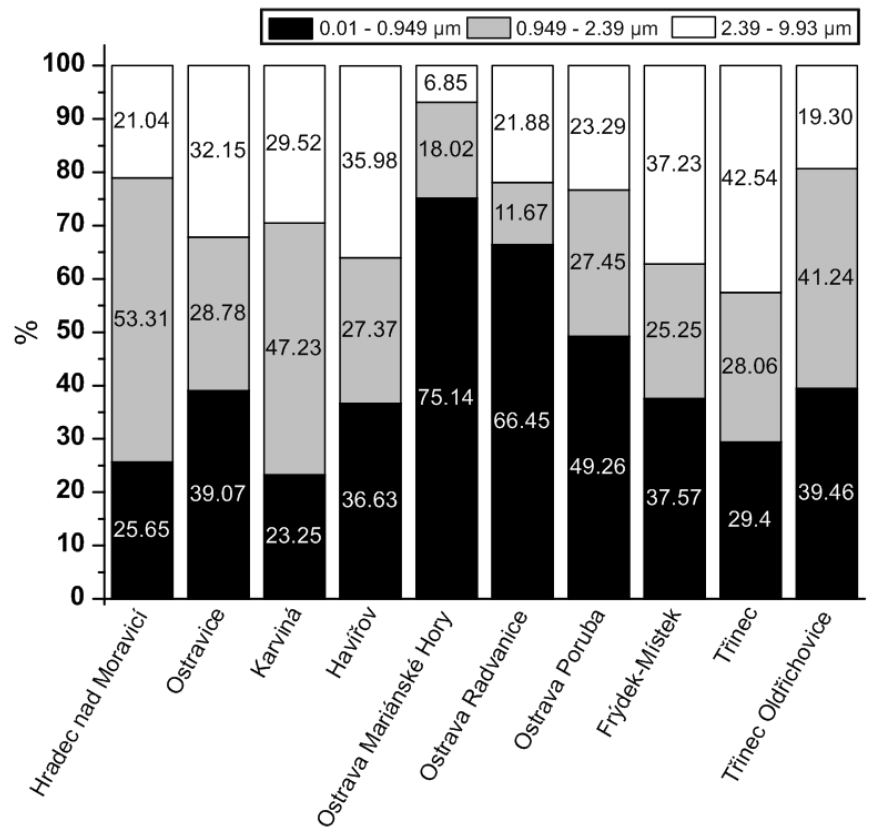

Figure 5. Distribution of Fe into classes in \%, at selected localities

A high proportion of fine-grained particles is probably related to remote particle transport or transport loads - Ostravice, Ostrava Poruba. For locations that will represent geochemical background, Ostrava Poruba and Hradec nad Moravicí were selected based on the presence of hematite and magnetite in TSP. Modelling of back trajectories using HYSPLIT, US. EPA - system for computing simple air parcel trajectories to complex dispersion and deposition simulations showed that at the time of sampling at the localities Hradec nad Moravicí and Ostrava Poruba, the air quality was uncharacteristically affected by pollution from the industrial city of Ostrava (during the year, the air masses most frequently move from NW direction from the Jeseníky Mountains).

\section{Correlation dependence for individual heavy metals}

Among the metals $\mathrm{Mn}-\mathrm{Cr}, \mathrm{Pb}-\mathrm{Cr}$, and $\mathrm{Cu}-\mathrm{Cr}$ in $\mathrm{PM}_{10}$ from metallurgical operations, significant correlation dependence can be found [21]. To identify the elemental associations within the particle size classes, the correlation analysis was performed using the Spearman correlation coefficient. The values $r=0.50$ were considered statistically significant, at the significance level $\alpha=0.05$.

In all the localities, significant correlation dependence for $\mathrm{Cr}$ with $\mathrm{Ni}, \mathrm{Mn}$, and $\mathrm{Zn}$, as well as between $\mathrm{Fe}$ and $\mathrm{Pb}, \mathrm{Zn}, \mathrm{Mn}, \mathrm{Ni}, \mathrm{Cr}, \mathrm{Ni}$ and $\mathrm{Mn}, \mathrm{Zn}$ and $\mathrm{Mn}-\mathrm{Zn}$ was observed. A statistically significant correlation relationship between $\mathrm{Cr}$ and $\mathrm{Zn}$ was demonstrated in all particle size classes except $\mathrm{PM}_{0.614-0.949}$. In this particle size class, no statistically significant correlation dependence between the elements was found. Between Fe-Zn, statistically significant correlation dependence was found in all particle size classes except $\mathrm{PM}_{0.0183-0.0937}$ and $\mathrm{PM}_{0.614-0.949}$. A statistically significant correlation relationship between $\mathrm{Ni}$ and $\mathrm{Mn}$ within the whole set is conditioned by dependency in the class

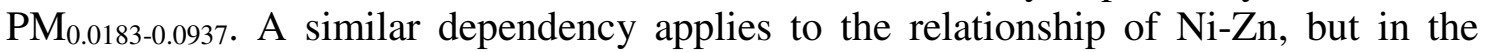
particle size class $\mathrm{PM}_{0.0937-0.156}$. Using the microanalysis of particles, occurrence of Fe-oxide particles containing $\mathrm{Co}, \mathrm{Cr}, \mathrm{Cu}, \mathrm{Ni}, \mathrm{Mn}$, and $\mathrm{Zn}$ was confirmed, which follows from the identified correlation dependencies between the elements. Correlation between $\mathrm{Pb}$ and $\mathrm{Fe}$ in fine-grained classes can be explained by common presence of sulphates, when in the locality Ostrava Radvanice, common occurrence of $\mathrm{Pb}-\mathrm{Ca}-\mathrm{SO}_{4}$ (containing $\mathrm{Pb} 2.23 \%$ ) and bianchite was proven. Fe-oxide particles with the admixture of $\mathrm{Pb}$ were not identified on the microprobe. 


\section{Percentages of metals in particle size classes}

The distribution of heavy metals in $\mathrm{PM}_{0.0937}$ (Aitken mode), $\mathrm{PM}_{0.156-0.949}$ (Accumulation mode), $\mathrm{PM}_{1.6-2.39}$ (fine $\mathrm{PM}$ ) and $\mathrm{PM}_{4-9.93}$ (coarse PM) varies depending on the considered element and the given locality.

For localities of group III and IV, heavy metals are mostly concentrated in particle size classes 156 to $949 \mathrm{~nm}$ (more than $32 \%$ of the total amount of heavy metals) and 1.6-4 $\mu \mathrm{m}$ (above 33\%). The exception for Ostrava Poruba is $\mathrm{Ni}\left(65 \%\right.$ in $\left.\mathrm{PM}_{0.0937}\right)$ and for the locality Karviná it is $\mathrm{Cr}(38 \%$, in the interval 4-9.93 $\mu \mathrm{m})$. For the localities I and II, the distribution of heavy metals in the individual particle size classes is more variable. At the localities Havírov and Frýdek Místek, most metals are concentrated in the particle size range from 156 to $949 \mathrm{~nm}$ (above 37\%) and from 4 to $9.93 \mu \mathrm{m}$ (above 36\%). The only exception is $\mathrm{Cd}$ (47\% $\mathrm{PM}_{1.6-2.39)}$ at the locality Frýdek Místek. Differing distribution of heavy metals can be found for Ostrava Mariánské Hory, where all metals except Ni (45\% in $\mathrm{PM}_{1.6-2.39}$ ) are concentrated in $\mathrm{PM}_{0.156-0.949}$ (over $56 \%$ of the total concentration of heavy metals). Also for the locality Radvanice, heavy metals are accumulated in the PM particle size range from 156 to $949 \mathrm{~nm}$ (above 43\%). The only exception is copper, which is mainly accumulated in $\mathrm{PM}_{4-9.93}(42 \%)$. Most variable distribution in terms of heavy metals is shown by the locality Trinec. The metals $\mathrm{Cu}$ and $\mathrm{Ni}$ are concentrated in the range from 18.3 to $93.7 \mathrm{~nm}(100 \%)$, the metals $\mathrm{Cd}, \mathrm{Sb}, \mathrm{Zn}$, and $\mathrm{Tl}$ in $\mathrm{PM}_{0.156-0.949}$ (above 37\%) and $\mathrm{Cr}, \mathrm{Pb}, \mathrm{Mn}$ and $\mathrm{Fe}$ in the particle size range from 4 to $9.93 \mu \mathrm{m}$ (above $42 \%$ ). A similar situation is also in Trrinec Oldřichovice, where the metals $\mathrm{Cd}, \mathrm{Pb}, \mathrm{Mn}$, and $\mathrm{Zn}$ are concentrated in $\mathrm{PM}_{0.156-0.949}$ (over 38\%), the metals $\mathrm{Cr}$, and $\mathrm{Fe}$ are mostly accumulated in particulate matter with an aerodynamic diameter of 1.6-2.39 $\mu \mathrm{m}$ (above $41 \%)$ and $\mathrm{Cu}$ was found only in PM smaller than $93.7 \mathrm{~nm}(100 \%)$.

Table 2 shows the percentage of the sum of heavy metals in the individual particle size classes for the groups of the localities divided by the content of hematite and magnetite in TSP (impact of the metallurgical industry). The highest percentage of heavy metals can be observed for particle size class $<9.93 \mu \mathrm{m}, 0.949-1.6 \mu \mathrm{m}$, and $0.0937-0.156 \mu \mathrm{m}$. Higher proportion of the sum of heavy metals in coarser particles over $1.6 \mu \mathrm{m}$ is associated with the re-suspension of PM during the summer months; soil erosion, abrasion of tires, construction activities, metallurgy. The influence of higher incidence of heavy metals in coarser particles emitted from transportation is reported in the literature [22].

Table 2. The percentage of the sum of heavy metals in the PM particle size classes

\begin{tabular}{ccccc}
\hline & Localities of group I & Localities of group II & Localities of group III & Localities of group IV \\
\hline$[\mu \mathrm{m}]$ & {$[\%]$} & {$[\%]$} & {$[\%]$} & {$[\%]$} \\
\hline $0.0183-0.0937$ & $0.001-0.2$ & $0.04-0.2$ & $0.03-0.3$ & $0.2-0.3$ \\
$0.0937-0.156$ & $0.1-0.6$ & $0.1-9.1$ & $0.1-0.4$ & $0.3-0.5$ \\
$0.156-0.263$ & $0.04-0.2$ & $0.04-0.1$ & $0.03-0.1$ & $0.4-1.1$ \\
$0.263-0.383$ & $0.04-0.3$ & $0.04-0.4$ & $0.02-0.04$ & $0.2-0.3$ \\
$0.383-0.614$ & $0.1-1.5$ & $0.3-3.4$ & $0.1-0.1$ & $0.3-3.1$ \\
$0.614-0.949$ & $0.2-0.3$ & $0.4-1.7$ & $0.1-0.7$ & $0.3-0.9$ \\
$0.949-1.6$ & $0.3-4.7$ & $0.5-3.0$ & $0.1-2.3$ & $5.6-6.4$ \\
$1.6-2.39$ & $0.2-1.4$ & $0.3-1.6$ & $0.2-1.3$ & $1.1-4.4$ \\
$2.39-6.69$ & $0.1-0.6$ & $0.1-1.3$ & $0.05-0.6$ & $0.2-1.0$ \\
$6.69-9.93$ & $1.0-2.2$ & $0.1-5.9$ & $0.3-8.3$ & $8.6-10.9$ \\
$<\mathrm{PM}_{1}$ & $0.07-0.32$ & $0.13-0.58$ & $0.05-0.17$ & $0.34-0.58$ \\
$\mathrm{PM}_{1-2.5}$ & $0.22-2.94$ & $0.44-2.17$ & $0.14-1.54$ & $2.66-4.86$ \\
$\mathrm{PM}_{2.5-10}$ & $0.36-0.77$ & $0.08-2.7$ & $0.12-1.65$ & $1.48-2.28$ \\
V $\sum$ PM & $0.2-0.6$ & $0.2-0.7$ & $0.1-0.4$ & $0.9-1.0$ \\
\hline The highest percentage & The second highest percentage \\
\hline \multicolumn{5}{c}{}
\end{tabular}

The lowest percentage occurrence of the sum of heavy metals was found in the smallest particles in the range from 0.0183 to $0.383 \mu \mathrm{m}$. After the particle size 
distribution into three typical groups below $\mathrm{PM}_{1} ; \mathrm{PM}_{1-2.5}$ a $\mathrm{PM}_{2.5-10}$, it was found that most metals occur in particle size class $\mathrm{PM}_{1-2.5}$. For locations not affected by the metallurgical industry, the highest content of heavy metals was found in $\mathrm{PM}_{2.5-10}$. From these results, it is evident that within the study of the distribution of heavy metals in the individual classes, the localities of group IV cannot be regarded as background ones.

\section{DISCUSSION AND CONCLUSIONS}

From the results of this study it was found that sum of heavy metals does not exceed $2.5 \%$ of total concentration of PM. It is an optimistic finding in the region with pronounced consequences of intensive industrial and metallurgical activities. The negative influence of heavy metals on human organism is not so important, compared with the original assumption when relatively much higher concentrations of heavy metals were expected. Alarming information is that most of the studied heavy metals are accumulated in particles of grain size $\mathrm{PM}_{1-2.5}$. It is known that these particles can penetrate deeply into pulmonary alveolar. Concentrations of heavy metals originate in substantial proportions from traffic sources, long-distance transport, and also other industrial sources.

The percentages of the sum of heavy metals in the sum PM at all the localities amounted to $0.2-2.5 \%$. The occurrence of heavy metals in different particle size classes of dust particles in the air within the Moravian-Silesian Region is variable. At the localities Hradec nad Moravicí, Karviná, and Havírov, a higher percentage of most of heavy metals was found in PM > $1.6 \mu \mathrm{m}$. At the localities Ostravice, Ostrava Marianské Hory, and Ostrava Radvanice, higher proportions of most heavy metals in $\mathrm{PM}<0.949 \mu \mathrm{m}$ were found.

$\mathrm{Cr}, \mathrm{Mn}, \mathrm{Fe}$, and $\mathrm{Zn}$ are mostly accumulated in the dust particles with a diameter greater than $1.6 \mu \mathrm{m}$. Fe, Mn, and Zn occurred at 8 of 10 localities in PM > $1.6 \mu \mathrm{m}$, only the localities Ostrava Marianské Hory and Ostrava Radvanice were different (over 66\% occurred in $\mathrm{PM}_{0.949)}$.

$\mathrm{Pb}, \mathrm{Cd}$, and $\mathrm{Sb}$ occurred mainly in the class below $0.949 \mu \mathrm{m}$. At 8 of 10 localities, cadmium occurred in the particle size class $\mathrm{PM}<0.949 \mu \mathrm{m}$, with the exception of Hradec nad Moravicí and Ostrava Poruba.

The influence of metallurgical industry on the basis of heavy metals in the individual particle size classes in the air within the Moravian-Silesian Region has not been unequivocally demonstrated. In the samples taken, the microanalysis was used to identify particles that are formed during metallurgical processes: Fe-oxides containing $\mathrm{Co}, \mathrm{Cr}$, $\mathrm{Cu}, \mathrm{Mn}, \mathrm{Ni}$, and $\mathrm{Zn}$, and iron-based particles based on silicates containing: $\mathrm{Ca}-\mathrm{Mg}-\mathrm{K}$ in various proportions, originating from combustion processes. Further, in particles below $1 \mu \mathrm{m}$, sulphates of $\mathrm{Zn}-\mathrm{Fe}$ and $\mathrm{Pb}-\mathrm{Ca}$, which affect the correlation between the content of $\mathrm{Fe}$ and $\mathrm{Pb}$ were proven.

\section{ACKNOWLEDGEMENT}

This paper was supported by the research projects of the Ministry of Education, Youth and Sport of the Czech Republic: The National Programme for Sustainability LO1404 - TUCENET and SP2015/64 - The Interdisciplinary Study of Fuel Behaviour and SP2015/63 - The research in the field of thermal conversions.

\section{REFERENCES}

1. Wichmann, H., Sprenger, R., Wobst, M. and Bahadir M., Combustion Induced Transport of Heavy Metals in the Gas Phase - A Review, Fresenius Environmental Bulletin, No. 9, pp 72-125, 2000. 
2. Moreno, T., Querol, X., Alastuey, A., Viana, M., Salvador, P., Sánchez De La Campa, A., Artiñano, B., De La Rosa, J. and Gibbons, W., Variations in Atmospheric PM Trace Metal Content in Spanish Towns: Illustrating the Chemical Complexity of the Inorganic Urban Aerosol Cocktail, Atmospheric Environment, Vol. 40, No. 35, pp 6791-6803, 2006, http://dx.doi.org/10.1016/j.atmosenv.2006.05.074

3. Buekens, A., Pollution Control Technologies: Vol. I - Dust-Particle Formation and Characteristics, Brussels: Encyclopedia of Life Support Systems (EOLSS), 2003.

4. Poulakis, E., Theodosi, C., Bressi, M., Sciare, J., Ghersi, V. and Mihalopoulos, N., Airborne Mineral Components and Trace Metals in Paris Region: Spatial and Temporal Variability, Environmental Science and Pollution Research, Vol. 22, No. 19, 2015, http://dx.doi.org/10.1007/s11356-015-4679-0

5. Mbengue, S., Alleman, L. Y. and Flament, P., Size-distributed Metallic Elements in Submicronic and Ultrafine Atmospheric Particles from Urban and Industrial Areas in Northern France, Atmospheric Research, Vol. 135-136, pp 35-47, 2014, http://dx.doi.org/10.1016/j.atmosres.2013.08.010

6. Espinosa, A. J. F., Rodriguez, M. T., De La Rosa, F. J. B. and Sanchez, J. C. J., Size Distribution of Metals in Urban Aerosols in Seville (Spain), Atmospheric Environment, Vol. 35, No. 14, pp 2595-2601, 2001, http://dx.doi.org/10.1016/S1352-2310(00)00403-9

7. Allen, A. G., Nemitz, E., Shi, J. P., Harrison, J. P. and Greenwood, J. C., Size Distributions of Trace Metals in Atmospheric Aerosols in the United Kingdom, Atmospheric Environment, Vol. 35, No. 27, pp 4581-4591, 2001, http://dx.doi.org/10.1016/S1352-2310(01)00190-X

8. Manoli, E., Voutsa, D. and Samara, C., Chemical Characterization and Source Identification Apportionment of Fine and Coarse Air Particles in Thessaloniki, Greece, Atmospheric Environment, Vol. 36, pp 949-961, 2002, http://dx.doi.org/10.1016/S1352-2310(01)00486-1

9. World Health Organization - WHO, Health Risks of Heavy Metals from Long-range Transboundary Air Pollution, WHO Regional Office for Europe: Copenhagen, Denmark, 2007.

10. Yadav, S. and Rajamani, V., Air Quality and Trace Metal Chemistry of different Size Fractions of Aerosols in NNW India - Implications for Source Diversity, Atmospheric Environment, Vol. 40, No. 4, pp 698-712, 2006, http://dx.doi.org/10.1016/j.atmosenv.2005.10.005

11. Özden, Ö., Döğeroğlu, T. and Kara, S., Assessment of Ambient Air Quality in Eskişehir, Turkey, Environment International, Vol. 34, No. 5, pp 678-687, 2008, http://dx.doi.org/10.1016/j.envint.2007.12.016

12. Nouri, J., Khorasani, N., Lorestani, B., Karami, M., Hassani, A. H. and Yousefi, N., Accumulation of Heavy Metals in Soil and Uptake by Plant Species with Phytoremediation Potential, Environmental Earth Science, Vol. 59, No. 2, pp 315-323, 2009, http://dx.doi.org/10.1007/s12665-009-0028-2

13. Mohanraj, R., Azeez, P. A. and Priscilla, T., Heavy Metals in Airborne Particulate Matter of Urban Coimbatore, Environmental Contamination and Toxicology, Vol. 47, No. 2, pp 162-167, 2004, http://dx.doi.org/10.1007/s00244-004-3054-9

14. Cabada, J. C., Rees, S., Takahama, S., Khlystov, A., Pandis, S. N., Cliff, I., Davidson, C. I. and Robinson, A. L., Mass Size Distributions and Size Resolved Chemical Composition of Fine Particulate Matter at the Pittsburgh Supersite, Atmospheric Environment, Vol. 38, No. 20, pp 3127-3141, 2004, http://dx.doi.org/10.1016/j.atmosenv.2004.03.004

15. Roth, E., Kehrli, D., Bonnot, K. and Trouvé, G., Size Distributions of Fine and Ultrafine Particles in the City of Strasbourg: Correlation between Number of Particles and Concentrations of $\mathrm{NO}_{\mathrm{x}}$ and $\mathrm{SO}_{2}$ Gases and Some Soluble Ions Concentration 
Determination, Journal of Environmental Management, Vol. 86, No. 1, pp 282-290, 2008, http://dx.doi.org/10.1016/j.jenvman.2006.12.022

16. Journet, E., Balkanski, Y. and Harrison, S. P., A New Data Set of Soil Mineralogy for Dust-cycle Modeling, Atmospheric Chemistry and Physics, Vol. 14, No. 8, pp 3801-3816, 2014, http://dx.doi.org/10.5194/acp-14-3801-2014

17. Menéndez, I., Díaz-Hernández, J. L., Mangas, J., Alonso, I. and Sánchez-Soto, P. J., Airborne Dust Accumulation and Soil Development in the North-east Sector of Gran Canaria, Journal of Arid Environments, Vol. 71, No. 1, pp 57-81, 2007, http://dx.doi.org/10.1016/j.jaridenv.2007.03.011

18. Matysek, D., Raclavska, H. and Raclavsky, K., Correlation between Magnetic Susceptibility and Heavy Metal Concentrations in Forest Soils of the Eastern Czech Republic, Journal of Environmental and Engineering Geophysics, Vol. 13, No. 1, pp 13-26, 2008, http://dx.doi.org/10.2113/JEEG13.1.13

19. Muránszky, G., Óvári, M., Virág, I., Csiba, P., Dobai, R. and Záray, G., Chemical Characterization of $\mathrm{PM}_{10}$ Fractions of Urban Aerosol, Microchemical Journal, Vol. 98, No. 1, pp 1-10, 2011, http://dx.doi.org/10.1016/j.microc.2010.10.002

20. Zhang, G. X., Lou, S., Li, L., Wang, H., Wang, X., Zhou, Z., Sheng, G., Fu, J. and Chen, Ch., Source and Mixing State of Iron-containing Particles in Shanghai by Individual Particle Analysis, Chemosphere, Vol. 95, pp 9-16, 2014, http://dx.doi.org/10.1016/j.chemosphere.2013.04.046

21. Querol, X., Alastuey, A., Viana, M. M. and Moreno, T., Inorganic Tracers of Source Pollution of PM, Barcelona, Spain, 2008.

22. Pastuszka, J. S., Rogula-Kozłowska, W. and Zajusz-Zubek, E., Characterization of $\mathrm{PM}_{10}$ and $\mathrm{PM}_{2.5}$ and Associated Heavy Metals at the Crossroads and Urban Background Site in Zabrze, Upper Silesia, Poland, during the Smog Episodes, Environmental Monitoring and Assessment, Vol. 168, No. 1-4, pp 613-627, 2009, http://dx.doi.org/10.1007/s10661-009-1138-8 